\title{
Yield and nutritional value of BRS Capiaçu grass at different regrowth ages
}

\section{Produtividade e valor nutricional do Capim-Elefante cv. BRS Capiaçu em diferentes idades de rebrota}

\author{
Flávio Pinto Monção ${ }^{1 *}$; Marco Aurélio Moraes Soares Costa²; João Paulo Sampaio \\ Rigueira ${ }^{3}$; Marielly Maria Almeida Moura ${ }^{4}$; Vicente Ribeiro Rocha Júnior ${ }^{3}$; Virgílio \\ Mesquita Gomes ${ }^{3}$; Dijair Barbosa Leal ${ }^{5}$; Camila Maida Albuquerque Maranhão \\ Carlos Juliano Brant Albuquerque ${ }^{6}$; Julieta Maria Alencar Chamone ${ }^{3}$
}

\begin{abstract}
The objective was to evaluate the productivity, chemical composition, ruminal degradability of dry matter and digestibility of BRS capiaçu grass (Pennisetum purpureum Schum.) managed at five regrowth ages. A completely randomized design with ten replications was used in the BRS capiaçu elephant grass subjected to five cutting intervals $(30,60,90,120$ and 150 days) in the summer, making a total of 50 plots with a useful area of $4 \times 2 \mathrm{~m}$. There were daily increases in the dry matter production in the order of $382 \mathrm{~kg} \mathrm{ha}^{-1}$, with $49,859 \mathrm{~kg} \mathrm{ha}^{-1}$ being produced at 150 regrowth days. The dry matter content and organic matter linearly increased $(\mathrm{P}<0.01)$ at different regrowth ages. The crude protein content, in vitro dry matter digestibility and in vitro digestibility of neutral detergent fiber linearly reduced $(\mathrm{P}<$ $0.01) 0.037 \%, 0.196 \%$ and $0.256 \%$ per day, respectively. Potential degradability of dry matter decreased from $68.9 \%$ at 30 days to $44.7 \%$ at 150 regrowth days ( 0.194 percentage units per day). The rate of degradation of fraction $\mathrm{B}$ ' $\mathrm{c}$ ' was not modified $(\mathrm{P}=0.94)$, averaging $1.46 \%$ hour $^{-1}$. In the cultivation of BRS capiaçu elephant grass in the summer season, in the northern region of Minas Gerais, the age for harvesting between 90 and 120 days of regrowth is recommended.
\end{abstract}

Key words: Ruminal kinetics. Chemical composition. Forage. Pennisetum purpureum. Forage production.

\section{Resumo}

Objetivou-se avaliar a produtividade, composição químico-bromatológica, degradabilidade ruminal da matéria seca e digestibilidade do Capim-Elefante-BRS capiaçu (Pennisetum purpureum Schum.) manejado em cinco idades de rebrota. Foi utilizado o delineamento inteiramente casualizado com dez repetições, na cultivar BRS capiaçu de capim-elefante submetida a cinco intervalos de corte $(30,60$,

1 Pós-Doutorando, Prof. Colaborador, Universidade Estadual de Montes Claros, UNIMONTES, Janaúba, MG, Brasil. E-mail: moncaomoncao@yahoo.com.br

2 Discente, Curso de Mestrado do Programa de Pós-Graduação em Zootecnia, UNIMONTES, Janaúba, MG, Brasil. E-mail: mamscosta@gmail.com

3 Profs., UNIMONTES, Janaúba, MG, Brasil. E-mail: joao.rigueira@unimontes.br; vicente.rocha@unimontes.br; virgilio. gomes@unimontes.br; zoomaida@hotmail.com; jmchamone@gmail.com

4 Prof ${ }^{a}$, Faculdades Unidas do Norte de Minas, FUNORTE, Montes Claros, MG, Brasil. E-mail: mary.sully@hotmail.com

5 Discente, Curso de Graduação em Zootecnia, UNIMONTES, Janaúba, MG, Brasil. E-mail: dijairleal@hotmail.com

6 Prof., Universidade Federal de Minas Gerais, UFMG, Montes Claros, MG, Brasil. E-mail: carlosjulianobrant@gmail.com

* Author for correspondence 
90, 120 e 150 dias) no verão, perfazendo um total de 50 parcelas com área útil de $4 \times 2 \mathrm{~m}$. Foram verificados incrementos diários na produção de matéria seca na ordem de $382 \mathrm{~kg} \mathrm{ha}^{-1}$, sendo 49.859 $\mathrm{kg} \mathrm{ha}^{-1}$ a produção aos 150 dias de rebrota. $\mathrm{O}$ teor de matéria seca e matéria orgânica aumentaram $(\mathrm{P}<$ $0,01)$ linearmente nas diferentes idades de rebrota. $\mathrm{O}$ teor de proteína bruta, digestibilidade in vitro da matéria seca e digestibilidade in vitro da fibra em detergente neutro reduziram $(\mathrm{P}<0,01)$ linearmente de $0.037 \%, 0.196 \%$ e $0.256 \%$ por dia, respectivamente. A degradabilidade potencial da matéria seca reduziu de $68.9 \%$ aos 30 dias para $44.7 \%$ com 150 dias de rebrota ( 0.194 unidades percentuais por dia). A taxa de degradação da fração $B$ 'c' não foi modificada ( $\mathrm{P}=0.94)$, média de $1.46 \%$ hora $^{-1}$. No cultivo do Capim-Elefante BRS capiaçu na estação verão, na região norte de Minas Gerais, recomenda-se a idade para colheita entre 90 e 120 dias de rebrota.

Palavras-chave: Cinética ruminal. Composição química. Forragem. Pennisetum purpureum. Produção de forragem.

\section{Introduction}

Ruminant production in Brazil is based on the use of forage crops as the main source of nutrients for animals (SAMPAIO et al., 2017). However, due to changes in climatic conditions throughout the year, there are variations in forage production and quality whose consequence is the low productivity of the herd. The use of fresh cultivation (weeds) has been one of the alternatives used by farmers to achieve a balance between the need for roughage and animal production during the period of forage shortage (PEREIRA et al., 2017).

Elephant grass (Pennisetum purpureum Schum.) stands out for its high dry matter production per unit area and nutritional value, being cultivated in several regions of the world (WIJITPHAN et al., 2009; ZAILAN et al., 2016; RIGUEIRA et al., 2018), resisting unfavorable climatic conditions, such as drought and cold. In this sense, Embrapa dairy cattle has focused on the crosses between several grasses of the species Pennisetum purpureum Schum. aiming to obtain more productive cultivars (PEREIRA et al., 2017). According to the same authors, the cultivar BRS capiaçu has been outstanding for presenting dry matter production around 33\% higher than Cameroon and Mineiro (average of 33.3 $t$ ha $^{-1}$ year $^{-1}$ ), considered the most productive of the species. However, since it is a recently introduced forage, research on cutting and nutritional value is still scarce, and studies are required to ensure the longevity of pasture and the correct formulation of feed for animals.

In weed management, the cutting frequency or height influences the productivity and the quality of the harvested forage (ZAILAN et al., 2016). Longer cutting intervals result in increases in mass production, however, there is a reduction in the nutritional value of the forage produced. Zailan et al. (2016) evaluated four cultivars of elephant grass (Cameroon, Silver, Dwarf and Purple Botucatu) subjected to three cutting intervals (4, 6 and 8 weeks) and verified increases in dry matter and cell wall production and reduction in the content of compounds and digestibility when the cutting interval increased from 4 to 8 weeks. However, the authors concluded that it is necessary to establish the best cutting interval for each grass, even of the same species, in order to balance the quantity and nutritional quality of the forage produced. Thus, it is necessary to predict the nutritional value of BRS capiaçu by means of analysis of chemical composition and rumen degradability tests in order to know the best age or height for cutting, either for fresh supply to the animals or for silage production.

Based on the above, the goal was to evaluate the productivity, chemical composition, rumen degradability of dry matter and digestibility of nutrients of BRS capiaçu grass managed at five regrowth ages $(30,60,90,120$ and 150 days $)$ in the summer. 


\section{Material and Methods}

All procedures involving animals were previously approved by the institutional committee on animal use of the Universidade Estadual de Montes Claros (CEBEA-UNIMONTES, number 175/2018).

The experiment was conducted at the Experimental Farm of UNIMONTES, in the municipality of Janaúba, state of Minas Gerais, from November 14, 2017 to April 14, 2018. The municipality of Janaúba is located in the Northern region of Minas Gerais (geographical coordinates: $15^{\circ} 52$ '38 "S, $43^{\circ} 20$ '05" W). The climate of the region, according to the classification of Reboita et al. (2015) is Aw with summer rains and well-defined dry periods in the winter. The average annual rainfall is $876 \mathrm{~mm}$, with an annual average temperature of $24^{\circ} \mathrm{C}$. The climate is mesothermal tropical, almost megathermal, due to the altitude, sub-humid and semiarid, with irregular rains, causing long periods of drought. The climatic data during the experimental period can be seen in Figure 1.

Figure 1. Climatic data during the experimental period.

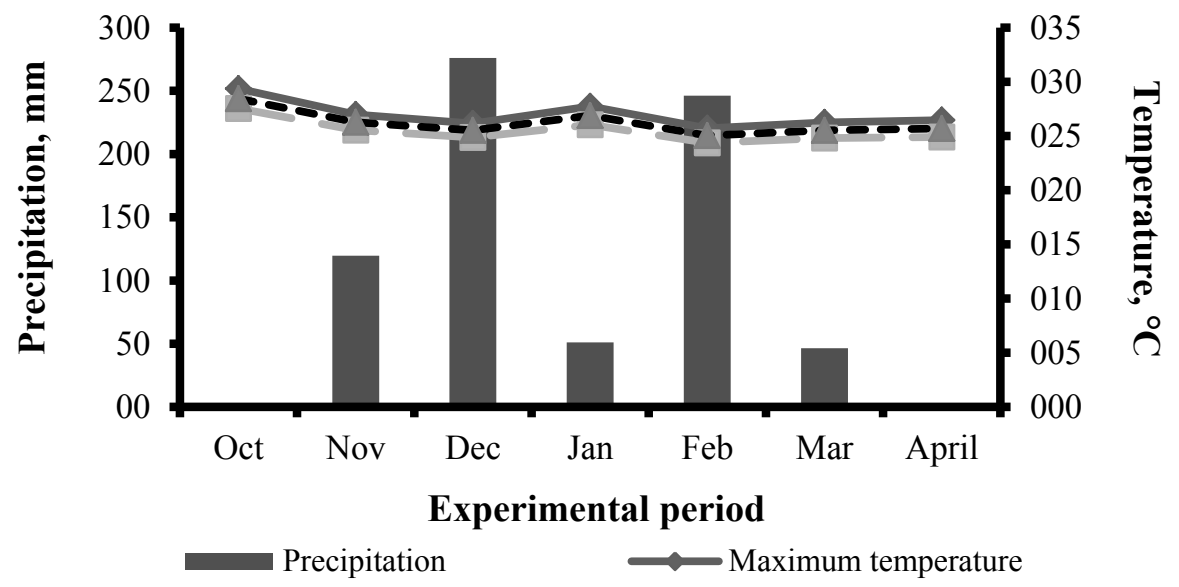

Source: National Institute of Meteorology (INMET, 2018).

The experiment was conducted in a flat area (93 m x $10 \mathrm{~m}$ ) with BRS capiaçu elephant grass (Pennisetum purpureum Schum.), already established (Planted) since 2016, on a dystrophic red-yellow soil with the following chemical characteristics: $\mathrm{pH}$ in $\mathrm{CaCl}_{2}, 4.3$; $\mathrm{P}$ (Mehlich): 3.0 mmol dm${ }^{-3}$; K (Mehlich): $1.5 \mathrm{mmol} \mathrm{dm}^{-3} ; \mathrm{Ca}^{2+}(\mathrm{KCl}$ $1 \mathrm{~mol} \mathrm{~L}): 10 \mathrm{mmol} \mathrm{dm}^{-3} ; \mathrm{Mg}^{2+}(\mathrm{KCl} 1 \mathrm{~mol} / \mathrm{L}): 4.0$ mmol dm${ }^{-3} ; \mathrm{Al}^{3+}(\mathrm{KCl} 1 \mathrm{~mol} / \mathrm{L}): 5.0 \mathrm{mmol} \mathrm{dm}^{-3}$ : $\mathrm{H}+\mathrm{A} 1$ (calcium acetate $0.5 \mathrm{~mol} \mathrm{~L}^{-1}$ ): $24 \mathrm{mmol} \mathrm{dm}$ ${ }^{-3}$ : sum of bases: $15.5 \mathrm{mmol} \mathrm{dm}^{-3}$; Cation exchange capacity: $39.5 \mathrm{mmol} \mathrm{dm}^{-3}$ : V: $39 \%$.

On November 13, 2017, the area was applied with $10 \mathrm{t} \mathrm{ha}^{-1}$ cattle manure with the following chemical characteristics: $\mathrm{pH}, 8.4$; moisture, $21.7 \%$ natural matter; Organic matter, $48.8 \%$ dry matter; Organic carbon, $28.3 \%$ dry matter; Nitrogen $(\mathrm{N})$, $1.1 \%$, phosphorus $\left(\mathrm{P}_{2} \mathrm{O}_{5}\right) ; 1.3 \%$, potassium $\left(\mathrm{K}_{2} \mathrm{O}\right)$, 3.4\%; Calcium oxide $(\mathrm{CaO}), 2.8 \%$; Magnesium oxide $(\mathrm{MgO}), 1.1 \%$; Sulfur sulfate $\left(\mathrm{SO}_{4}\right), 0.2 \%$; Copper (Cu), $0.01 \mathrm{mg} \mathrm{kg}^{-1}$, Iron (Fe), $1.28 \mathrm{mg} \mathrm{kg}^{-}$ 1; Manganese, $0.08 \mathrm{mg} \mathrm{kg}^{-1}$; Zinc, $0.02 \mathrm{mg} \mathrm{kg}^{-1}$. A completely randomized design with the cultivar BRS Capiaçu elephant grass subjected to five cutting intervals $(30,60,90,120$ and 150 days) and ten replications was used, making a total of 50 plots with $6.0 \times 3,0 \mathrm{~m}$ each and a useful area of 4 $\mathrm{x} 2 \mathrm{~m}$. The regrowth ages were chosen due to the high growth of BRS Capiaçu grass, as verified in previous studies (PEREIRA et al., 2017). 
Planting of BRS capiaçu grass in spaced rows of 1.3 meters was carried out using seedlings (cuttings) from Embrapa dairy cattle. On November 11, 2017, the sward was subjected to standardization cut, manual, close to the soil, and applied with $50 \mathrm{~kg} \mathrm{ha}^{-1}$ NPK (04-30-10) and the experimental days were counted. After each cutting, $50 \mathrm{~kg} \mathrm{ha}{ }^{-1} \mathrm{NPK}$ of the same formula was applied. After soil amendment, it presented the following chemical characteristic: $\mathrm{pH}$ in $\mathrm{CaCl}_{2}, 6.3$; $\mathrm{P}$ (Mehlich), $7.8 \mathrm{mg} \mathrm{dm}^{-3}$; $\mathrm{K}$ (Mehlich), $187 \mathrm{mg} \mathrm{dm}^{-3} ; \mathrm{Ca}^{2+}, 2.9 \mathrm{cmolc} \mathrm{dm}^{-3} ; \mathrm{Mg}$ ${ }^{2+}, 0.7 \mathrm{cmolc} \mathrm{dm}^{-3} ; \mathrm{Al}^{3+}, 0.0$ cmolc dm ${ }^{-3} ; \mathrm{H}+\mathrm{A} 1$ (calcium acetate $0.5 \mathrm{~mol} \mathrm{~L}^{-1}$ ), $1.7 \mathrm{cmolc} \mathrm{dm}^{-3}$; base sum $4.2 \mathrm{cmolc} \mathrm{dm}^{-3}$; Cation exchange capacity, 5.9 cmolc dm ${ }^{-3}$; Base saturation (V), 71\%. The height of the plants was measured in 3 points per plot using a scale, graduated in meters, at the time of harvest at each age, from the ground to the insertion of the last leaf blade of the plants.

After each pre-established regrowth age, a $1 \mathrm{~m}^{2}$ metal frame was used to manually collect the forage samples, close to the soil, and to estimate the green matter production (GMP) by area. The GMP was estimated based on the number and spacing of the rows. The samples were pre-dried in a forced ventilation oven at $55^{\circ} \mathrm{C}$ to constant weight. The dry matter production (DMP) was estimated based on GMP multiplied by pre-dried matter content at each regrowth age.

The pre-dried forage was analyzed for dry matter (DM, 934.01), crude ash (942.05), ether extract (EE; 920,39) and crude protein (CP, 978,04), according to AOAC (1995). Neutral detergent fiber (NDF) and acid detergent fiber (ADF) were determined by the sequential method according to procedures described by Robertson and Van Soest (1981) using a Tecnal ${ }^{\circledR}$ TE-149 fiber determiner (Piracicaba, SP, Brazil). Cellulose was solubilized in $72 \%$ sulfuric acid and the lignin content was obtained from the resulting weight difference (GOERING; VAN SOEST, 1970). Total carbohydrates (TC) were estimated using the following formula: $\mathrm{TC}=100$ - $(\% \mathrm{CP}+\%$ ash $+\%$ EE $)$, according to Detmann et al. (2012). Total digestible nutrients were estimated according to NRC (2001).

The in vitro digestibility of dry matter, organic matter, crude protein and neutral detergent fiber was determined according to the methodology described by Tilley and Terry (1963) adapted by Detmann et al. (2012), using the in vitro incubator of Tecnal ${ }^{\circledR}$ (TE-150; Piracicaba, SP, Brazil), with modified bag material $(7.0 \times 7.0 \mathrm{~cm})$, made with TNT $(100$ $\mathrm{g} \mathrm{m}^{-2}$ ). The method used for in vitro digestibility simulates a ruminal digestion for 48 hours, followed by a digestion with pepsin and weak acid $(\mathrm{pH})$ for another 48 hours.

To evaluate the ruminal degradation kinetics, four crossbred, male, castrated steers equipped with rumen cannulas, average weight of $500 \pm 70 \mathrm{~kg}$, received $3.0 \mathrm{~kg}$ concentrate in two equal meals, in the morning and afternoon and diets based on BRS capiaçu elephant grass. The in situ degradability technique was carried out in $7.5 \times 15 \mathrm{~cm}$ non-woven fabric bags (TNT) (weight 100) with approximate porosity of $60 \mu \mathrm{m}$, according to Casali et al. (2009); the number of samples was determined from the ratio of $20 \mathrm{mg}$ of DM.cm ${ }^{-2}$ of bag surface area (NOCEK, 1988).

The bags were placed in filo bags of $20 \times 30 \mathrm{~cm}$, along with 100 grams of lead. Filo bags were tied with nylon thread, leaving a length of $1 \mathrm{~m}$ so that the bags could move freely in the solid and liquid phases of the rumen. Bags were then deposited in the region of the ventral sac of the rumen with the tip of the nylon thread remaining attached to the cannula for $0,3,6,12,24,48,72,96$ and 120 hours in reverse order, that is, starting with the duration of 120 hours. The bags related to time zero were not incubated in the rumen, but were washed in running water, similar to incubated bags. To estimate the indigestible fraction of NDF, the samples were incubated in two cattle for 288 hours (DETMANN et al., 2012). Subsequently, the samples were placed in an oven at $55^{\circ} \mathrm{C}$ for 72 hours and then cooled in a desiccator and weighed. 
Residues remaining in TNT bags collected in the rumen were analyzed for DM content. The percentage of degradation was calculated by the proportion of food remaining in the bags after ruminal incubation.

Data obtained were fit to a non-linear regression by the Gauss-Newton method (NETER et al., 1985), using SAS software (SAS, 2008), according to the equation proposed by Ørskov and McDonald (1979): $\mathrm{Y}=\mathrm{a}+\mathrm{b}\left(1-\mathrm{e}^{-\mathrm{ct}}\right)$, where: $\mathrm{Y}=$ accumulated degradation of the nutrient component analyzed after time $\mathrm{t} ; \mathrm{a}=$ degradation curve intercept when $\mathrm{t}$ $=0$, which corresponds to the water soluble fraction of the analyzed nutrient component; $b=$ degradation potential of the water insoluble fraction of the analyzed nutrient component; $\mathrm{a}+\mathrm{b}=$ potential degradation of the nutrient component analyzed when time is not a limiting factor; $\mathrm{c}=$ degradation rate by fermentative action of $b ; t=$ incubation time.

After calculating, the coefficients $a, b$ and $c$ were applied to the equation proposed by Ørskov and Mcdonald (1979): $\mathrm{DE}=\mathrm{a}+(\mathrm{bxc} / \mathrm{c}+\mathrm{k})$, where: $\mathrm{DE}=$ effective rumen degradability of the nutrient component analyzed; $\mathrm{k}=$ rate of feed passage. Rumen particle passage rates estimated at $5 \% \mathrm{~h}^{-1}$, as suggested by AFRC (1993), were assumed.

Data on chemical composition and in vitro digestibility were tested by analysis of variance and regression using the PROC GLM and REG procedure of SAS version 9.4 (SAS, 2008), respectively, at 5\% probability, according to the model: $\mathrm{Yij}=\mu+\mathrm{Ti}+\varepsilon \mathrm{ij}$, where Yij $=$ observation of the effect of treatment $i$ on the repetition $j ; \mu=$ overall mean; $\mathrm{Ti}=$ treatment effect applied in plot, with $\mathrm{i}=1,2,3,4$ and 5 ; $\varepsilon \mathrm{ijk}=$ random error associated with each observation.

For the in situ dry matter degradability variables, a split plot randomized complete block was used, with five regrowth ages (plots), nine incubation times (subplots) and four blocks. The different weights of the animals were the blocking factor. Data were tested by analysis of variance and regression using the MIXED and REG procedure of SAS, version 9.4 (SAS, 2008), respectively, at $5 \%$ probability, according to the model: Yijk $=\mu+$ $\tau i+$ Time $j+\tau i x$ Time $j+\varepsilon i j k$, where: Yijk is the observation ijk; $\mu$, the overall mean; $\tau$ i, the fixed effect of the treatment applied to the plot, with $i=1$, 2, 3, 4 and 5; Time, fixed effect of incubation time $j$ to subtract; the random effect of animal k; Ti x Time $j$, the interaction effect of treatment $i$ and time $j$; عijk, the random error with mean 0 and variance $\sigma^{2}$.

Comparisons between the regrowth ages were performed by breakdown of the sum of squares in orthogonal linear contrasts and quadratic effects, with $5 \%$ probability, with subsequent adjustments of the regression equations.

\section{Results and Discussion}

As the regrowth age increased from 30 to 150 days, there was a linear increase $(\mathrm{P}<0.01)$ in height, green mass production (GMP) and dry matter production (DMP; Table 1). The height of the plant increased $79.31 \%$, ranging from 1.03 meters with 30 days to 4.98 meters with 150 regrowth days. This increase occurred due to genetic factors inherent to the species (PEREIRA et al., 2017) and to the amount of light needed by the plant. Sunlight limitation for leaf blades can stimulate stem growth as a strategy for exposing the leaf to the solar radiation required for photosynthesis (SANTOS et al., 2017).

For each day increase in the regrowth age, there was an increase of 0.035 meters in the canopy height (Table 2). The height increase favors greater stem accumulation, consequently, higher GMP and DMP. In this study, significant daily increments were recorded in GMP and DMP, in the order of $1,280 \mathrm{~kg} \mathrm{ha}^{-1}$ and $382 \mathrm{~kg} \mathrm{ha}^{-1}$, respectively. 
Table 1. Structure, production and nutritional value of BRS capiaçu grass at different ages of regrowth in the summer.

\begin{tabular}{|c|c|c|c|c|c|c|c|c|}
\hline \multirow{2}{*}{ Item $(\%)$} & \multicolumn{5}{|c|}{ Age of regrowth (days) } & \multirow{2}{*}{ SEM } & \multicolumn{2}{|c|}{ Contrasts } \\
\hline & 30 & 60 & 90 & 120 & 150 & & Linear & Quadratic \\
\hline Height, $\mathrm{m}$ & 1.03 & 1.93 & 3.43 & 4.50 & 4.98 & 0.12 & $<0.01$ & $<0.01$ \\
\hline GMP, kg/ha & 36077 & 63385 & 125077 & 145385 & 187154 & 8542 & $<0.01$ & 0.70 \\
\hline DMP, kg/ha & 4502 & 9282 & 23783 & 33291 & 49859 & 4065 & $<0.01$ & 0.24 \\
\hline Dry matter & 11.69 & 13.80 & 17.50 & 21.25 & 24.33 & 1.33 & $<0.01$ & 0.69 \\
\hline Crude ash & 15.44 & 12.07 & 9.75 & 7.88 & 8.71 & 0.50 & $<0.01$ & $<0.01$ \\
\hline Organic matter & 84.56 & 87.93 & 90.25 & 92.12 & 91.29 & 0.50 & $<0.01$ & $<0.01$ \\
\hline Crude protein & 12.32 & 10.64 & 7.72 & 8.74 & 7.71 & 0.27 & $<0.01$ & $<0.01$ \\
\hline Ether extract & 1.04 & 1.24 & 1.16 & 1.06 & 1.34 & 0.07 & 0.08 & 0.64 \\
\hline NDF & 61.28 & 65.55 & 69.73 & 75.02 & 72.25 & 1.89 & $<0.01$ & 0.08 \\
\hline $\mathrm{ADF}$ & 38.77 & 42.11 & 45.17 & 52.94 & 48.27 & 1.23 & $<0.01$ & 0.02 \\
\hline Hemicelullose & 22.50 & 23.44 & 24.57 & 22.08 & 23.98 & 1.54 & 0.75 & 0.77 \\
\hline Celullose & 26.42 & 33.81 & 34.60 & 36.05 & 34.06 & 1.06 & $<0.01$ & $<0.01$ \\
\hline Lignin & 5.02 & 6.11 & 6.99 & 8.30 & 7.77 & 0.50 & $<0.01$ & 0.15 \\
\hline NFC & 9.92 & 10.49 & 11.64 & 7.30 & 9.99 & 2.11 & 0.65 & 0.88 \\
\hline $\mathrm{TC}$ & 71.20 & 76.04 & 81.37 & 82.32 & 82.25 & 0.60 & $<0.01$ & $<0.01$ \\
\hline TDN & 43.32 & 43.14 & 42.45 & 39.65 & 41.69 & 0.92 & 0.03 & 0.51 \\
\hline IVDMD & 67.76 & 64.95 & 50.48 & 47.17 & 47.23 & 1.41 & $<0.01$ & $<0.01$ \\
\hline IVOMD & 56.52 & 73.62 & 60.19 & 62.52 & 61.51 & 4.77 & 0.94 & 0.27 \\
\hline IVCPD & 64.48 & 63.85 & 61.06 & 59.71 & 58.00 & 2.65 & $<0.01$ & 0.05 \\
\hline IVNDFD & 53.69 & 50.15 & 33.00 & 28.05 & 25.95 & 2.11 & $<0.01$ & 0.07 \\
\hline iNDF & 32.72 & 30.71 & 40.28 & 42.82 & 44.92 & 2.81 & $<0.01$ & 0.10 \\
\hline
\end{tabular}

GMP - Green matter production; DMP - Dry matter production; NDF - neutral detergent fiber; ADF - acid detergent fiber; NFCNon-fibrous carbohydrates; TC - Total carbohydrates; IVDMD - in vitro dry matter digestibility; IVOMD - in vitro organic matter digestibility; IVNDFD - in vitro neutral detergent fiber digestibility; iNDF- indigestible neutral detergent fiber. SEM - Standart error of the means.

Table 2. Regression equations for variables on BRS capiaçu grass managed at different age of regrowth in summer.

\begin{tabular}{lcc}
\hline \multicolumn{1}{c}{ Variables } & Regression equation & $\mathrm{R}^{2}$ \\
\hline Height, meters & $\hat{\mathrm{Y}}=0.033+0.035 * \mathrm{X}$ & 0.92 \\
Green matter production, $\mathrm{kg} / \mathrm{ha}$ & $\hat{\mathrm{Y}}=-3830+1280 * \mathrm{X}$ & 0.98 \\
Dry matter production, $\mathrm{kg} / \mathrm{ha}$ & $\hat{\mathrm{Y}}=-10274+382 * \mathrm{X}$ & 0.97 \\
Dry matter & $\hat{\mathrm{Y}}=7.89+0.109 * \mathrm{X}$ & 0.99 \\
Crude ash & $\hat{\mathrm{Y}}=16.07-0.0588 * \mathrm{X}$ & 0.84 \\
Organic matter & $\hat{\mathrm{Y}}=83.92-0.0588 * \mathrm{X}$ & 0.84 \\
Crude protein & $\hat{\mathrm{Y}}=12.76-0.037 * \mathrm{X}$ & 0.85 \\
Ether extract & $\hat{\mathrm{Y}}=1.17$ & - \\
Neutral detergente fiber & $\hat{\mathrm{Y}}=59.34+0.104 * \mathrm{X}$ & 0.83 \\
Acid detergente fiber & $\hat{\mathrm{Y}}=36.50+0.099 * \mathrm{X}$ & 0.74 \\
Hemicellulose & $\hat{\mathrm{Y}}=23.31$ & -
\end{tabular}

continue 
continuation

Celullose

Lignin

Non-fibrous carbohydrates

Total Carbohydrates

Total digestible nutrients

in vitro dry matter digestibility

in vitro organic matter digestibility

in vitro crude protein digestibility

in vitro neutral detergent fiber digestibility

indigestible neutral detergent fiber

$$
\begin{array}{cc}
\hat{Y}=18.68+0.31 * X-0.0014 * X^{2} & 0.95 \\
\hat{Y}=4.52+0.025 * X & 0.86 \\
\hat{Y}=9.87 & - \\
\hat{Y}=70.12+0.094 * X & 0.84 \\
\hat{Y}=44.07-0.022 * X & 0.52 \\
\hat{Y}=73.16-0.196 * X & 0.86 \\
\hat{Y}=62.87 & - \\
\hat{Y}=66.55-0,057 * X & 0.97 \\
\hat{Y}=61.43-0.258 * X & 0.91 \\
\hat{Y}=27.33-0.1217 * X & 0.84
\end{array}
$$

*: significant for $\mathrm{t}$ test's at $\mathrm{P}<0.01$.

Pereira et al. (2017) verified DMP of the BRS capiaçu grass of $49.75 \mathrm{t} \mathrm{ha}^{-1} \mathrm{DM}$ with a height of 4.2 meters, whereas in this study, this production was found at 150 days of age, $49.85 \mathrm{tha}^{-1} \mathrm{DM}$ with 4.98 meters. These variations in height are due to soil and climatic changes and spacing. Although the highest DMP was verified with 150 days of regrowth, the operational management of cutting can be compromised, since, in practice, grass lodging due to strong winds.

Dry matter and organic matter (OM) increased linearly at different regrowth ages. As the regrowth age increased, there was a $51.95 \%$ increase in DM content $\left(0.109 \%\right.$ day $\left.^{-1}\right)$. This is because as the plant reaches the physiological maturity, changes in the proportion of cell contents and cell walls occur, being verified, increases in the components of the cell wall to the detriment of cellular content (WILSON, 1994). As nitrogen compounds are present in the cellular content of young plants, as the regrowth age increases, there is a reduction or dilution in crude protein content, as observed in this study (linear reduction of $0.037 \%$ per day, $\mathrm{P}<0.01$ ), with an average of $12.32 \%$ at 30 days. Although the crude protein values observed in BRS capiaçu grass (12.32\% to $7.71 \%)$ were higher than the critical range of $6-8 \%$ dry matter, recommended for no reduction in microbial growth efficiency and fiber degradability (DETMANN et al., 2014), Velásquez et al. (2010) verified in tropical grasses that as the regrowth age increases, increases the indigestible fraction and slow ruminal degradation fraction of the crude protein.

The contents of neutral detergent fiber (NDF), acid detergent fiber (ADF), cellulose and lignin are the major components of the cell wall and these increased linearly with the increase in the regrowth age from 30 to 150 days. The NDF, ADF and lignin contents increased $0.104 \%, 0.099 \%$ and $0.025 \%$ day $^{-1}$, with averages at 30 regrowth days of $61.28 \%$, $38.77 \%$ and $5.02 \%$, respectively. This increase in the components of the cell wall is very important in the structural formation of the plant, especially the stem that sustains and exposes the leaf blade to sunlight (WILSON, 1994). However, its effect on the quality of the ruminant diet is not desirable because there may be a reduction in the digestibility of fiber components, reducing the passage rate of the digesta through the rumen, impairing the dry matter intake by the animal and, consequently, animal production (VAN SOEST, 1994; VELÁSQUEZ et al., 2010). In contrast, total digestible nutrients (TDN), in vitro dry matter digestibility (IVDMD), in vitro digestibility of crude protein (IVDCP) and in vitro digestibility of NDF (IVNDFD) decreased linearly with increasing regrowth age from 30 to 150 days, consequently, affecting the nutritional value of the forage. There was a daily reduction 
of $0.022 \%$ in TDN content, $0.196 \%$ in IVDMD, $0.057 \%$ in IVCPD and $0.256 \%$ in IVNDFD.

Velásquez et al. (2010) found that fractions A, $\mathrm{B} 1$ and B2 of crude protein reduced in forages, such as Tifton 85 (Cynodon spp.) and Marandu grass (Brachiaria), and B3 and $\mathrm{C}$ values increased with the cutting age. According to Russell et al. (1992), the reduction of fractions A, B1 and B2 may imply a lower supply of iso acids required by rumen microorganisms, as well as a consequence of microbial protein synthesis. For Van Soest (1994) and Velásquez et al. (2010), the fraction B3 is associated with the components of the cell wall of the plant and presents a very slow degradation rate, while the fraction $\mathrm{C}$ corresponds to the undegradable nitrogen. According to Sniffen et al. (1992) and Van Soest (1994), the composition of fraction B3 and fraction $\mathrm{C}$ consists of amino acids and nitrogen compounds bound to lignin, tannic-protein complexes and Maillard reaction products that are resistant to the attack of enzymes of microbial origin and from the host.

On the fiber components, the reduction in the IVNDFD is justifiable. The thickening of the secondary cell wall with maturation of plant tissues increases the concentration of neutral detergent fiber and lignin to the detriment of cell contents (WILSON, 1994; VAN SOEST, 1994, ZAILAN et al., 2016) as can be seen with the increase in the indigestible neutral detergent fiber (INDF), which increased $0.127 \%$ day $^{-1}$. Lignin is not digestible by rumen microorganisms because it is toxic (JUNG; DEETZ, 1993), and in the cell wall of plants it is structurally strongly bound to hemicellulose (ester-type bond) with increasing regrowth age (JUNG; DEETZ, 1993; VAN SOEST, 1994). This bond is responsible for reducing the ruminal digestibility of the fiber compounds, which is the major source of carbohydrates for ruminants on pasture. According to Jung and Deetz (1993), the reduction in digestibility of fiber components can be affected by lignin in three ways: 1) toxic effect on the population of rumen microorganisms caused by the presence of coumaric acid that is released during digestion of the cell wall; 2) causing physical impairment by the lignin-polysaccharide binding, which limits the access of fibrolytic enzymes; and 3) by the hydrophobic action resulting from the lignin polymers, limiting the action of the hydrophilic enzymes, whose activity is done in an aqueous environment.

The increase in the age of cutting BRS capiaçu grass linearly reduced the readily soluble fraction (fraction A), insoluble but potentially degradable fraction (fraction B) and the effective degradability (ED) of DM (Table 3). The fraction A reduced $0.0908 \%$ for each day increase in the regrowth age, while the potential degradability (PD) and DE were $0.1943 \%$ and $0.1405 \%$, respectively. This behavior is justified because the plant, as it reaches the physiological maturity, promotes thickening of the supporting tissues, such as cell wall, associated with lignification process (WILSON, 1994), where fraction $\mathrm{B}$ is found, with proportional decrease of cell content, where the fraction A is located (VAN SOEST, 1994). Consequently, $\mathrm{PD}$ and ED are affected. The degradation rate "c" of fraction B was not modified $(\mathrm{P}=0.94)$, with a mean of $1.46 \%$ hour $^{-1}$.

Table 3. Rumen degradability of dry matter of BRS capiaçu grass managed at different ages of regrowth in summer.

\begin{tabular}{|c|c|c|c|c|c|c|c|c|}
\hline \multirow{2}{*}{ Item } & \multicolumn{5}{|c|}{ Age of regrowth (day) } & \multirow{2}{*}{ SEM } & \multicolumn{2}{|c|}{ Contrasts } \\
\hline & 30 & 60 & 90 & 120 & 150 & & Linear & Quadratic \\
\hline Fraction $\mathrm{a}^{1}$ & 21.35 & 18.13 & 14.75 & 13.39 & 10.10 & 0.62 & $<0.01$ & 0.40 \\
\hline Fraction $b^{2}$ & 48.45 & 44.26 & 43.67 & 40.92 & 34.61 & 3.84 & 0.01 & 0.62 \\
\hline c, $\% / h$ & 2.0 & 2.0 & 1.0 & 1.00 & 1.00 & $<0.1$ & 0.94 & 0.94 \\
\hline
\end{tabular}


continuation

$\begin{array}{lllllllll}\mathrm{PD}^{3} & 69.80 & 62.39 & 58.42 & 54.31 & 44.70 & 4.04 & <0.01 & 0.72 \\ \mathrm{ED}^{4} & 32.91 & 30.88 & 22.75 & 20.53 & 17.01 & 0.41 & <0.01 & 0.03 \\ \mathrm{UF}^{5} & 30.20 & 37.61 & 41.58 & 45.69 & 55.30 & 4.04 & <0.01 & 0.72\end{array}$

Fraction a- fraction readily soluble; Fraction b - fraction insoluble in water, but potentially degradable; c - rate of degradation of fraction b; PD - Potential degradability; ED - Effective degradability ( $\mathrm{k}=0.05)$; UF - Undegradable fraction. Standard error of the means; *: significant for $\mathrm{t}$ test's at $\mathrm{P}<0.01$.

${ }^{1} \hat{Y}=23.71-0.0908 * X, R^{2}=0.98 ;{ }^{2} \hat{Y}=51.68-0.1034 * X, R^{2}=0.92 ;{ }^{3} \hat{Y}=75.40-0.1943 * X, R^{2}=0.97 ;{ }^{4} \hat{Y}=37.46-0.1405 * X, R^{2}$ $=0.95 ;{ }^{5} \hat{\mathrm{Y}}=24.59+0.1943 * \mathrm{X}, \mathrm{R}^{2}=0.97$.

The undegradable fraction increased linearly $\left(0.1943 \%\right.$ day $\left.^{-1}\right)$ with the increase in regrowth age, which is explained by the lignin behavior in the cell wall. Pereira et al. (2017) evaluated the nutritional value of BRS capiaçu with 4.2 meters of height, and verified $9.1 \%$ crude protein, $71.5 \% \mathrm{NDF}$ and $54.76 \%$ IVDMD. These values are close to those observed in this study. However, it is not recommended to manage the grass at heights higher than 4.5 meters, although higher mass productivity was verified; but above that height, it was observed lodging of the plant, making difficult the operational harvest management. Pereira et al. (2017) recommended the management of BRS capiaçu between 90 and 110 days or with 4.2 meters. Zailan et al. (2016) studied the best regrowth age for harvesting four varieties of Pennisetum purpureum Schum. and recommended cuts every 60 days on the Cameroon and Purple variety. For BRS capiaçu, the harvest window between 90 and 120 days would be ideal because they have high productivity of digestible mass per unit area. In addition, the DM content is close to that recommended for ensiling the mass produced, although moisture reducing additives are recommended to raise the DM content to at least 28\% (FERRARETTO et al., 2018; BORREANI et al., 2018).

\section{Conclusion}

The increase in the age of BRS capiaçu grass increased the dry matter yield per unit area in detriment of the nutritional value, characterized by the reduced digestibility and degradability of the dry matter fractions and the digestibility of the fiber fraction. Nevertheless, for cultivation in the northern region of Minas Gerais, age for harvesting between 90 and 120 days of regrowth is recommended.

\section{Acknowledgements}

The authors thank the Foundation for Research Support of the State of Minas Gerais (FAPEMIG), the Embrapa Gado de Leite, the National Council for Scientific and Technological Development (CNPq), INCT- Animal Science and UNIMONTES, Pró-Reitoria de Pesquisa for scholarships.

This study was financed in part by the Coordenação de Aperfeiçoamento de Pessoal de Nível Superior - Brasil (CAPES) - Finance Code 001.

\section{References}

AGRICULTURALAND FOOD RESEARCH COUNCIL - AFRC. Energy and protein requirements of ruminants. Walligford: CAB International, 1993.

ASSOCIATION OF OFFICIAL ANALYTICAL CHEMISTS - AOAC. Official methods of analysis of AOAC international. $16^{\text {th }}$ ed. Arlington: Association of Official Analytical Chemists, 1995.

BORREANI, G.; TABACCO, E.; SCHMIDT, R. J.; HOLMES, B. J.; MUCK, R. E. Silage review: factors affecting dry matter and quality losses in silages. Journal of Dairy Science, Madison, v. 101, n. 1, p. 3952-3979, 2018. DOI: $10.3168 /$ jds.2017-13837

CASALI, A. O.; DETMANN, E.; VALADARES FILHO, S. C.; PEREIRA, J. C.; CUNHA, M.; DETMANN, K. S. C.; PAULINO, M. F. Estimação de teores de componentes 
fibrosos em alimentos para ruminantes em saco de diferentes tecidos. Revista Brasileira de Zootecnia, Viçosa, MG, v. 38, n. 1, p. 130-138, 2009. DOI: 10.1590/ S1516-35982009000100017

DETMANN, E.; SOUZA, M. A.; VALADARES FILHO, S. C.; QUEIROZ, A. C.; BERCHIELLI, T. T. Methods for food analysis. Visconde do Rio Branco, Viçosa, MG: Suprema, 2012. 214 p.

DETMANN, E.; VALENTE, E. E. L.; BATISTA, E. D.; HUHTANEN, P. An evaluation of the performance and efficiency of nitrogen utilization in cattle fed tropical grass pastures with supplementation. Livestock Science, Amsterdam, v. 162, n. 1, p. 141-153, 2014. DOI: 10.1016/j.livsci.2014.01.029

FERRARETTO, L. F.; SHAVER, R. D.; LUCK, B. D. Silage review: recent advances and future technologies for whole-plant and fractionated corn silage harvesting. Journal of Dairy Science, Madison, v. 101, n. 1, p. 3937 3951, 2018. DOI: $10.3168 /$ jds.2017-13728

GOERING, H. K.; VAN SOEST, P. J. Forage fiber analysis: apparatus, reagents, procedures and some applications. Washington: USDA, 1970. 20 p.

INSTITUTO NACIONAL DE METEREOLOGIA - INMET. Estações e dados/dados metereológicos. Brasília: On line, 2018. Disponível em: http://www. inmet.gov.br/portal/ . Acesso em: 27 jul. 2018.

JUNG, H. G.; DEETZ, D. A. Cell wall lignification and degradability. In: JUNG, H. G.; BUXTON, D. R.; HATFIELD, R. D.; RALPH, J. Forage cell wall structure and digestibility. Madison: American Society of Agronomy, 1993. p. 315-346.

NATIONAL RESEARCH COUNCIL - NRC. Nutrient requirements of beef cattle. Seventh Revised Edition. Whashington: The National Academies Press, 2006. p. 248. DOI: doi.org/10.17226/9791.

NETER, J.; WASSERMAN, W.; KUTNER, M. H. Applied linear statistical models. Regression, analysis of variance, and experimental designs. $2^{\text {th }}$ ed. Lake Tahoe: Richard D. Irwin, Inc., 1985. 1127 p.

NOCEK, J. E. In situ and other methods to estimate ruminal protein and energy digestibility: a review. Journal of Dairy Science, Madison, v. 71, n. 8, p. 20512069, 1988. DOI: 10.3168/jds.S0022-0302(88)79781-7

ØRSKOV, E. R.; MCDONALD, I. The estimation of degradability in the rumen form incubation measurement weighted according to rate of passage. Journal of Agricultural Science, Cambridge, v. 92, n. 1, p. 499-508, 1979. DOI: $10.1017 / \mathrm{S} 0021859600063048$
PEREIRA, A. V.; LÉDO, F. J. S.; MACHADO, J. C. BRS Kurumi and BRS Capiaçu - new elephant grass cultivars for grazing and cut-and-carry system. Crop Breeding and Applied Biotechnology, Viçosa, MG, v. 17, n. 1, p. 59-62, 2017. DOI: $10.1590 / 1984-70332017 v 17 n 1 c 9$

REBOITA, M. S.; RODRIGUES, M.; SILVA, L. F.; ALVES, M. A. Aspectos climáticos do estado de minas gerais. Revista Brasileira de Climatologia, Curitiba, v. 17, n. 1, p. 206-226, 2015. DOI: 10.5380/abclima. v17i0.41493

RIGUEIRA, J. P. S.; MONÇÃO, F. P.; SALES, E. C. J.; REIS, S. T.; BRANT, L. M. S.; CHAMONE, J. M. A.; ROCHA JÚNIOR, V. R.; PIRES, D. A. A. Fermentative profile and nutritional value of elephant grass silage with different levels of crude glycerin. Semina: Ciências Agrárias, Londrina, v. 39, n. 2, p. 833-844, 2018. DOI: 10.5433/1679-0359.2018v39n2p833

ROBERTSON, J. B.; VAN SOEST, P. J. The detergent system of analysis and its application to human foods. In: JAMES, W. P. T.; THEANDER, O. The analysis of dietary fiber in food. New York: Marcel Dekker, 1981. p. $123-158$.

RUSSELL, J. B.; O'CONNOR, J. D.; FOX, D. G.; VAN SOEST, P. J.; SNIFFEN, C. J. A net carbohydrate and protein system for evaluating cattle diets: I. Ruminal fermentation. Journal of Animal Science, Champaign, v. 70, n. 12, p. 3551-3561, 1992.

SAMPAIO, R. L.; RESENDE, F. D.; REIS, R. A.; OLIVEIRA, I. M.; CUSTÓDIO, L.; FERNANDES, R. M.; PAZDIORA, R. D.; SIQUEIRA, G. R. The nutritional interrelationship between the growing and finishing phases in crossbred cattle raised in a tropical system. Tropical Animal Health and Production, Edinburgh, v. 49, n. 5, p. 1015-1024, 2017. DOI: 10.1007/s11250-0171294-8

SANTOS, M. E.; SOUSA, B. M. L.; ROCHA, G. O.; FREITAS, C. A. S.; SILVEIRA, M. C. T.; SOUSA, D. O. C. Sward structure and tiller characteristics in piatã grass pastures managed with variable nitrogen doses and deferment periods. Ciência Animal Brasileira, Goiânia, v. 18 , n. $1-13$, p. $1-13,2017$. DOI: 10.1590/1089$6891 \mathrm{v} 18 \mathrm{e}-37547$

SNIFFEN, C. J.; O'CONNOR, J. D.; VAN SOEST, P. J.; FOX, D. G.; RUSSELL, J. B. A net carbohydrate and protein system for evaluating cattle diets: II. Carbohydrate and protein availability. Journal Dairy Science, Madison, v.70, n.11, p. 3562-3577, 1992.

STATISTICAL ANALYSIS SYSTEM INSTITUTE SAS Institute. SAS/STAT 9.2 User's Guide. Cary: SAS Institute, Inc., 2008. 
TILLEY, J. M. A.; TERRY, R. A. A two-stage technique for the in vitro digestion of forage crops. Journal of the British Grassland Society, Londres, v. 18, n. 2, p. 104111, 1963. DOI: 10.1111/j.1365-2494.1963.tb00335.x

VAN SOEST, P. J. Nutritional ecology of the ruminant. $2^{\text {th }}$ ed. Corvallis: O \& B Books, 1994. 415 p.

VELÁSQUEZ, P. A. T.; BERCHIELLI, T. T.; REIS, R. A.; RIVERA, A. R.; DIAN, P. H. M.; TEIXEIRA, I. A. M. A. Composição química, fracionamento de carboidratos e proteínas e digestibilidade in vitro de forrageiras tropicais em diferentes idades de corte. Revista Brasileira de Zootecnia, Viçosa, MG, v. 39, n. 6, p. 1206-1213, 2010. DOI: $10.1590 / \mathrm{S} 1516-35982010000600007$
WIJITPHAN, S.; LORWILAI, P.; ARKASEANG, C. Effect of cutting heights on productivity and quality of king Napier grass (Pennisetum purpureum cv. King grass) under irrigation. Pakistan Journal of Nutrition, Sargodha, v. 8, n. 8, p. 1244-1250, 2009. DOI: $10.3923 /$ pjn.2009.1244.1250

WILSON, J. R. Cell wall characteristics in relation to forage digestion by ruminants: review. Journal Agriculture Science, Cambridge, v. 122, n. 2, p. 173-182, 1994. DOI: $10.1017 /$ S0021859600087347

ZAILAN, M. Z.; YAAKU, H.; JUSOH, S. Yield and nutritive value of four Napier (Pennisetum purpureum) cultivars at different harvesting ages. Agriculture and Biology Journal of North America, Salt Lake City, v. 7, n. 5, p. 213-219, 2016. DOI: 10.5251/abjna.2016.7.5.213.219 
